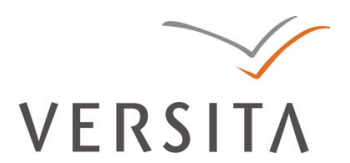

Folia Oeconomica Stetinensia

DOI: $10.2478 / \mathrm{v} 10031-012-0034-5$

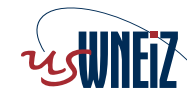

Wydzial Nauk Ekonomicznych i Zarządzania Uniwersytetu Szczecińskiego

\title{
MEASUREMENT OF THE EFFICIENCY OF MUTUAL FUNDS OPERATING ON THE PAN-EUROPEAN MARKET*
}

Dorota Witkowska, Prof.

Warsaw University of Life Sciences

Department of Econometrics and Statistics

Nowoursynowska 166, 02-787 Warszawa, Poland

e-mail:dorota_witkowska@sggw.pl

Received 10 October 2012, Accepted 17 April 2013

\begin{abstract}
In the paper the performance of 18 selected European mutual funds is evaluated. Analysis is conducted for 6 samples distinguished from the period 15.09.2006-20.01.2012. Ranking of funds is provided applying the aggregated measures that base on well known Sharpe, Treynor and Jensen ratios and four different markets indexes e.g. Euro STOXX 50, DAX, CAC 40 and FTSE 100. In the composite indicators construction we use 60 classifications of the mutual funds.
\end{abstract}

Keywords: mutual funds, performance ratios, capital market.

JEL classification: G1.

* Research has been conducted in frame of the Polish Government Project: Efficiency of open-end investment funds in changing economic situation N N111 277638. 


\section{Introduction}

Mutual fund assets have been increasing both in total and in relative numbers, for instance as a share of mutual fund assets in retirement plans. It means that even if we do not belong to the group of individuals or households owning mutual funds, their performance influences our future pensions.

The primary purpose for which mutual funds are acquired and held is for their expected good performance. Mutual funds are said to have "professional" managements which, presumably, provide the potential for investment results better than those that the layperson might achieve by selecting their own individual securities and subsequently managing their portfolio themselves. Mutual funds, however, are saddled with burdens which counterbalance the performance benefits derived from the "professionalism" of their managements. Therefore the analysis of mutual fund efficiency has been conducted since the 1960s by the academics and practitioners.

The global financial crisis, that has been lasting since 2007, is considered by many economists as the most serious after the Great Depression. It resulted in the threat of total collapse from large financial institutions, the bailout of banks by national governments, and the decline in stock markets around the world.

Thus two main questions arise. The first one regarding the efficiency of mutual funds that has been debated by academics since the seminal Jensen paper was published ${ }^{1}$. The second question is if the mutual fund managers can protect the wealth of their clients during a financial crisis. Therefore the aim of our research is to evaluate the performance of mutual funds that operate on the European market. The investigation is conducted for the time spam from September 11, 2006 to January 27, 2012, applying the aggregated measures that include the results of classical measurements of the investment portfolio efficiency, such as: rates of return, the Treynor, Sharpe and Jensen indexes. We also want to find out how the funds in question perform in different market situations caused by a financial crisis.

\section{Literature review}

Mutual fund performance rankings have been compiled on a regular and timely basis. Mutual funds that have a relatively high position in the rankings tout their performance prominently in their advertising while those that do not search for the measure that puts them in the best possible light ${ }^{2}$. The examination of past performance of managed portfolios has been 
a routine procedure and several scholars have documented that historical performance as the predominant criterion in fund selection ${ }^{3}$.

Wermers ${ }^{4}$ claims that although some controversy still exists, the majority of studies conclude that actively managed funds (e.g. the Fidelity Magellan fund ${ }^{5}$ ), on average, underperform their passively managed counterparts (e.g. the Vanguard Index 500 fund $^{6}$ ). Gruber ${ }^{7}$ finds that the "average" mutual fund underperforms passive market indexes and Carhart ${ }^{8}$ finds that net returns are negatively correlated with expense levels, which are much higher for actively managed funds. Ding and Wermers ${ }^{9}$ conduct a comprehensive analysis of the relation between the performance and governance structure of open-end, domestic-equity mutual funds. They show that experienced large-fund portfolio managers outperform their size, book-to-market, and momentum benchmarks, but that experienced small-fund portfolio managers underperform their benchmarks - indicating the presence of managerial entrenchment in the mutual fund industry. Recently, Bello and Frank ${ }^{10}$ have given the analysis regarding the impact of reduced expense ratio (by Security and Exchange Commission's regulations) in the US mutual fund performance. Their results show that both the expense ratio and the portfolio turnover are negatively related to investment performance. Hence, high expenses and high turnover tend to decrease performance (which is in line with previous studies).

Gil-Bazo and Ruiz-Verdú, basing on the US mutual funds, gave some surprising results that funds with worse before-fee performance charge higher fees ${ }^{11}$. It supported the idea given many years ago by Gruber ${ }^{12}$ that high fees are associated with inferior rather than superior management. Unlike earlier studies, Gil-Bazo and Ruiz-Verdú ${ }^{13}$ focus on the relation between before-fee performance and fees, and investigate whether differences in fees reflect differences in the value that mutual funds create for investors. Unexpectedly, they found a negative relationship between before-fee performance and fees in a sample of the US equity mutual funds.

Mutual funds efficiency has been documented by various researchers who have highlighted numerous factors influencing the mutual fund performance. The three traditional measures of the portfolio performance are the Treynor and Sharpe indexes, and Jensen's alpha. However there are a number of shortcomings of the above measures that have been highlighted in the literature since Treynor, Sharpe, and Jensen ${ }^{14}$ have developed portfolio evaluation models which are either based on the capital asset pricing model (CAPM) or bear a close relation to it. Fletcher reviews the theoretical conditions under which the Jensen performance measure provides valid inferences about fund performance ${ }^{15}$. The key assumptions are:

1. the unconditional mean-variance efficiency of the benchmark portfolio(s), 
2. the existence of a riskless asset,

3. no binding constraints on investors and

4. investors only possess selectivity (selective?) information.

Roll, Reilly and Akhtar, and Grinblatt and Titman show that efficiency evaluated by means of capital asset pricing models could be sensitive to the benchmark selection ${ }^{16}$. Evaluation techniques - specifically Jensen's - are statistically biased against successful market timers. Lehmann and Modest notice that the assessment of fund performance can vary with the benchmark and metrics selected ${ }^{17}$. They also found "statistically significant measured abnormal performance" across the various benchmarks, and left open the question as to the economic explanation for these phenomena. Matallin-Saez analyses the suitability of using factors or benchmarks to measure portfolio performance ${ }^{18}$. Empirical results reveal similar biases in extended Jensen's alphas in models with both factors and that the benchmark selection has a more important effect than the model type chosen.

Knowing that the choice of the benchmark may affect significantly the efficiency evaluation of the portfolio performance, there are two possible approaches to this issue. The first one consists of the benchmark selection among the existing instruments (i.e. market indexes may describe either the stock or mutual fund markets) while the second one is the construction "special" benchmarks. There are several examples of the first approach, for instance: Dutta et al. apply the Morgan Stanley Capital International world index (MSCI) ${ }^{19}$; Prince and Bacon use the Russell 2000 market index ${ }^{20}$; Otten and Bams, and Otten and Schweitzer employ for international comparison different "domestic" indexes such as: CAC for France, DAX for Germany, Mibtel for Italy, AEX for the Netherlands, FTSE All for the United Kingdom and S\&P 500 for the Unites States ${ }^{21}$; applies the SBF250 index ${ }^{22}$ while use the CISDM equity long/short index ${ }^{23}$. However there are also studies where the market index is specially (i.e. due to the aim of investigation) constructed, e.g. Karpio and Żebrowska-Suchodolska ${ }^{24}$ employ indexes from different parts of the world i.e.: All Ord Austral, B-Shares Shanghai, Buenos Aires, Budapest BUX, Frankfurt DAX, DJ Industrial, London FTSE 100, Hang Seng H. Kong, Mexic IPC, NASDAQ US, NIKKEI 225 Tokyo and TSE-300 Toronto.

Performance persistence has been the most popular topic in the mutual fund literature both in the 1990 s and in the third millennium ${ }^{25}$, to mention some examples of such research. The persistence studies have focused on the issue whether it is possible to predict future performance by using past performance records. The topic is very central from the viewpoint of the entire performance measurement industry since if the past performance had no prediction power over future performance, the data collecting and ex post performance evaluation would be 
a useless procedure from the investor's standpoint. Nevertheless, the performance measurement industry is growing all the time along with mutual fund markets. Companies like Morningstar and Lipper have started their business by publishing mutual fund rankings, and performance reviews are regularly published in Barron's, Business Week, Forbes and the Wall Street Journal ${ }^{26}$.

Mutual fund performance has been usually assessed separately for selected types of domestic fund ${ }^{27}$ because of data authenticity and availability, as it is done in research presented by Bangash, Otten and Bams, Otten and Schweitzer or Price and Bacon among others ${ }^{28}$. It is also worth mentioning that sample size in these investigations essentially vary from several funds (as in [Collinet, Firer 2003], [Droms, Walker 2001] who analyze 7 and 11 funds respectively ${ }^{29}$ ) to several thousands of funds (for instance Harlow and Brown ${ }^{30}$ consider 5,614 U.S. equity funds), and the great variety of the mutual funds selection criteria is applied. Also, the spam of time together with the length of the investigated period differ depending on the aim of an analysis, however the latter is usually not shorter than 5 years $^{31}$.

\section{Data selection}

Total worldwide assets invested in mutual funds at the end of 2011 equaled $\$ 23.8$ trillion $^{32}$. The USA has the world's largest mutual fund market that was worth $\$ 11.6$ trillion at the end of 2011 thus the share of US mutual funds assets was $49 \%$ of the worldwide market. Therefore the majority of literature regarding mutual funds focuses on the U.S. market due to the availability of historic data and the large share of the U.S. mutual fund industry relative to the global share in total net assets. Europe creates the second largest mutual fund market (see Figure 1) but studies of the European mutual fund industry are less frequent and they focus mostly on single country characteristics.

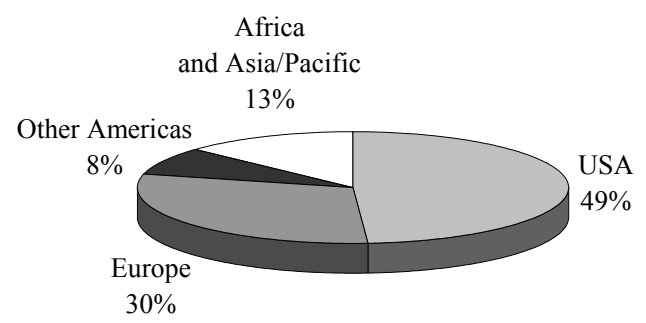

Fig. 1. Share of assets invested in the worldwide mutual fund market Source: 2012 Investment Company Fact Book, p. 25. 
In our research the analysis is conducted for the 18 best performing mutual funds operating in Europe that have been selected by means of Financial Times Fund Screener ${ }^{33}$ that allows to search among more than 80 thousands funds ${ }^{34}$, using more than 40 different criteria that belong to three groups:

1. fund type and market(s);

2. goal of the fund such as: allocation, alternative investments, commodities, emerging markets stock, fixed income, international, regional, sector or single country stock;

3. fund attributes like: performance, ratings, expense, etc.

In the mutual fund selection we employed the following criteria:

- investment focus - regional stock and the eurozone large-cap equity ${ }^{35}$ (to choose mutual funds that invest in the most liquid stocks from the 12 eurozone countries),

- 3-year and 5-year trailing total returns ${ }^{36}$ is to be bigger than 0 ,

- inception date should be at least 5 years before our investigation,

- equity is at least $75 \%$ instruments in the mutual fund portfolio,

- at least $75 \%$ of assets are invested in the EU but less than a half of assets is to be invested in one country.

On the basis of these criteria over 200 mutual funds were selected and put in descending order due to the 3-year trailing total return. Among them we chose 18 best performing funds due to the rule that there is only one fund representing a certain investment company in the sample because we assumed that all funds belonging to the same investment company were managed similarly. As can be seen in Table 1, all the selected mutual funds invested mainly at equity market.

Table 1. List of selected mutual funds

\begin{tabular}{|c|c|c|c|c|}
\hline \multirow{3}{*}{ Name of the fund } & \multirow{3}{*}{ Symbol } & \multirow{2}{*}{$\begin{array}{l}\text { 3-year } \\
\text { total return }\end{array}$} & \multicolumn{2}{|c|}{ Share of investment in } \\
\hline & & & equity & other \\
\hline & & \multicolumn{3}{|c|}{$\%$} \\
\hline 1 & 2 & 3 & 4 & 5 \\
\hline Allianz RCM Wachstum Euroland A EUR & Allianz & 18.61 & 99.63 & 0.37 \\
\hline AXA Rosenberg Eurobloc Equity Alpha Fund B EUR Acc & AXA & 4.01 & 98.88 & 1.12 \\
\hline BlackRock Global Funds - Euro-Markets A2 EUR & BlackRock & 12.31 & 99.84 & 0.16 \\
\hline Credit Suisse Aktien Plus A & $\mathrm{CS}$ & 7.18 & 99.21 & 0.79 \\
\hline Deka-EuroStocks CF Inc & Deka & 8.20 & 98.45 & 1.35 \\
\hline DWS Invest Top Euroland FC & DWS & 11.73 & 99.55 & 0.45 \\
\hline Fidelity Funds - Euro Blue Chip Fund A-EUR & Fidelity & 7.76 & 99.72 & 0.28 \\
\hline First Private Euro Aktien STAUFER A & FP & 7.27 & 99.14 & 0.86 \\
\hline Henderson Horizon Euroland Fund A2 & Henderson & 10.25 & 99.37 & 0.63 \\
\hline HL MaxInvest FT (FT-Frankfurt Trust) & FT & 7.76 & 91.06 & 8.94 \\
\hline
\end{tabular}




\begin{tabular}{|l|c|c|c|c|}
\hline \multicolumn{1}{|c|}{1} & 2 & 3 & 4 & 5 \\
\hline HSBC Global Investment Funds Euroland Equity A EUR & HSBC & 6.15 & 98.30 & 1.70 \\
\hline Pioneer Investments Euroaktien & Pioneer & 9.21 & 99.91 & 0.09 \\
\hline Ring Aktien Fonds DWS & RAF & 14.10 & 85.79 & 14.21 \\
\hline Schroder ISF Euro Equity A Acc & SI & 6.55 & 98.69 & 1.31 \\
\hline SEB EuroCompanies & SEB & 8.54 & 97.54 & 2.46 \\
\hline UniEuroAktie & UI & 7.14 & 97.81 & 2.19 \\
\hline UniExtra: EuroStoxx-50 & UIL & 8.18 & 89.78 & 10.22 \\
\hline VERI-EUROPA & Veritas & 7.17 & 99.51 & 0.49 \\
\hline
\end{tabular}

Source: own elaboration on the basis of: www.funds.ft.com, www.finanzen.net and Lachowski (2012).

Taking into account the structure of investment, in terms of the country and economic sector being the main investment focus ${ }^{37}$, we can see (Table 2) that the majority of selected mutual funds invest in companies located in France, Germany, the Netherlands and Spain, then - in Italy and Finland, while energy, telecom, finance and health care sectors seem to be the most "popular" economic branches selected for the mutual funds investments.

Table 2. Structure of investment portfolios of selected mutual funds

\begin{tabular}{|c|c|c|c|c|c|c|}
\hline No. & State & $\begin{array}{l}\text { Number } \\
\text { of funds } \\
\text { investing } \\
\text { in the } \\
\text { certain state }\end{array}$ & $\begin{array}{c}\text { Average share } \\
\text { of investments } \\
\text { made } \\
\text { in the certain } \\
\text { state }(\%)\end{array}$ & Economic sector & $\begin{array}{c}\text { Number } \\
\text { of funds } \\
\text { investing } \\
\text { in the certain } \\
\text { sector }\end{array}$ & $\begin{array}{c}\text { Average share } \\
\text { of investments } \\
\text { made } \\
\text { in the certain } \\
\text { sector }(\%)\end{array}$ \\
\hline 1. & France & 14 & 30.98 & Energy & 16 & 8.37 \\
\hline 2. & Germany & 14 & 29.89 & Telecom & 13 & 7.09 \\
\hline 3. & Holland & 14 & 9.61 & Finance & 12 & 16.59 \\
\hline 4. & Spain & 13 & 7.74 & Health care & 12 & 7.65 \\
\hline 5. & Italy & 12 & 6.57 & Consumption goods & 9 & 11.93 \\
\hline 6. & Finland & 9 & 4.01 & Industry & 9 & 12.98 \\
\hline 7. & Belgium & 7 & 3.41 & Logistics & 8 & 6.90 \\
\hline 8. & Portugal & 4 & 1.73 & Investment goods & 6 & 12.23 \\
\hline 9. & Austria & 4 & 1.62 & IT & 5 & 9.26 \\
\hline 10. & Luxemburg & 4 & 1.00 & Raw materials & 5 & 8.33 \\
\hline 11. & United Kingdom & 3 & 11.32 & Technology & 5 & 4.73 \\
\hline 12. & Ireland & 3 & 1.52 & Banking & 4 & 12.09 \\
\hline 13. & Sweden & 2 & 3.10 & Media \& entertainment & 3 & 15.18 \\
\hline 14. & Switzerland & 1 & 19.29 & Pharmacy & 3 & 9.79 \\
\hline 15. & Norway & 1 & 3.50 & Fuel & 3 & 8.07 \\
\hline 16. & Greece & 1 & 2.26 & Insurance & 3 & 7.33 \\
\hline 17. & Denmark & 1 & 1.00 & Automobile industry & 3 & 6.35 \\
\hline
\end{tabular}

Source: own elaboration on the basis of www.finanzen.net and Lachowski (2012).

We may also distinguish companies whose equities appear the most often in the portfolios of the examined mutual funds with the average share from $2.61 \%$ to $4.80 \%$ of total assets. These 
companies are: Total SA and Sanofi that belong to 10 portfolios, Siemens, BASF SA, SAP and Telefonica - 8 portfolios; BNP Paribas and Allianz - 7 and 6 mutual funds respectively, Unilever and Bayer - 5 funds, Banco Santander and ENI - 4 portfolios.

It is worth mentioning that the biggest share of investments made in one country is observed for Allianz that invests $41 \%$ of assets in France and Credit Suisse $-40.16 \%$ of investments are made on the German market. While the biggest share of investments made in one economic branch is observed for Veri-Europa that invests over $31 \%$ of assets in media \& entertainment. Siemens is the company with the largest share of assets $(9 \%)$ invested in one equity by Ring Aktien.

In our investigation the analysis is carried out for all selected mutual funds in the period from September 11, 2006 to January 15, 2012 which is divided into two sub-periods by the date of September 15, 2008 when Lehman Brothers Holdings Inc. (LB) declared bankruptcy. In addition, we also consider two equal-length sub-periods distinguished on the basis of Euro STOXX 50 index trend, covering bear and bull markets (see Figure 2) from July 2, 2007 to November 12, 2010, since the maximum value of Euro STOXX 50 index was observed on July 16, 2007 - 4557.57, and the minimal value on March 10, 2009 - 1809.98. In other words there are 6 periods of analysis, denoted as:

T1: from 2006.09.15 to 2008.09.15 (525 observations),

T2: from 2008.09.16 to 2010.09.15 (880 observations),

T: from 2006.09.15 to 2012.01.20 (1405 observations),

B1: from 2007.07.02 to 2009.03.06 (440 observations),

B2: from 2009.03.09 to 2010.11.12 (440 observations),

B: from 2007.07.02 to 2010.11.12 (880 observations).

\section{Methodology}

The aim of this research is to measure the performance of 18 selected open-ended mutual funds that operate on the pan-European market using classical efficiency measures. To evaluate the Treynor, Shape and Jensen ratios it is necessary to choose an instrument that is representative of the market index and risk free. Usually, when domestic investment is considered, both benchmarks represent the analyzed market regardless the discussion concerning the existence of such benchmarks or the way of their selection. In our case we deal with the "global" European market and we cannot point out a single market index since either investments are located in different countries or investors are residents of different states. Therefore in our research we apply four stock indexes describing the European market: 
1. Euro STOXX 50 (ES 50) representing the eurozone market ${ }^{38}$,

2. DAX representing German companies trading on the Frankfurt Stock Exchange,

3. CAC 40 - the French stock market index,

4. FTSE 100 - the London Stock Exchange index.

Plots of all the considered index quotations seem to follow similar tendencies (see Figure 2).

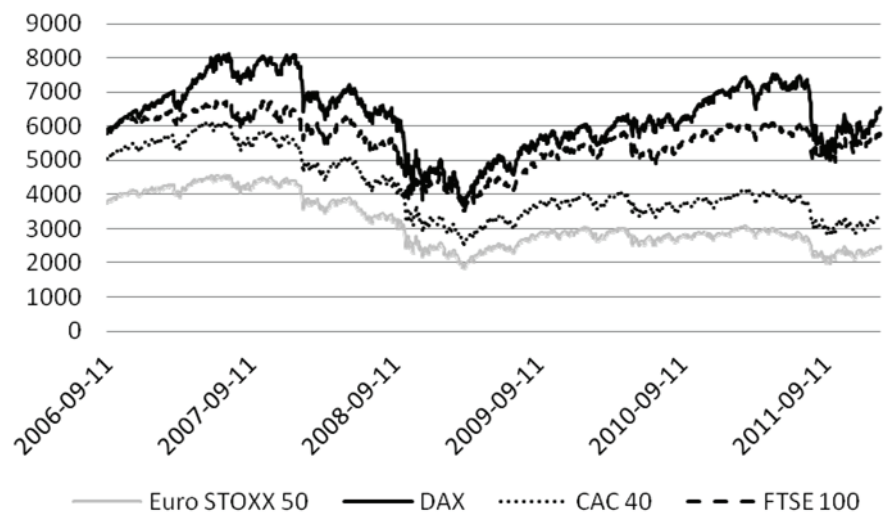

Fig. 2. Comparison of the European stock index quotations

Source: www.finanzen.net.

The German Treasury 10-year bill: Bundesrepublik Deutschland-Anleihe bis 15-04-2016 (BDA) is used as a risk free instrument for the pan-European market because German economy seems to recover relatively quickly from the financial crisis and the German 10-year T-bill seems to be stable in the analysed period (see Figure 3).

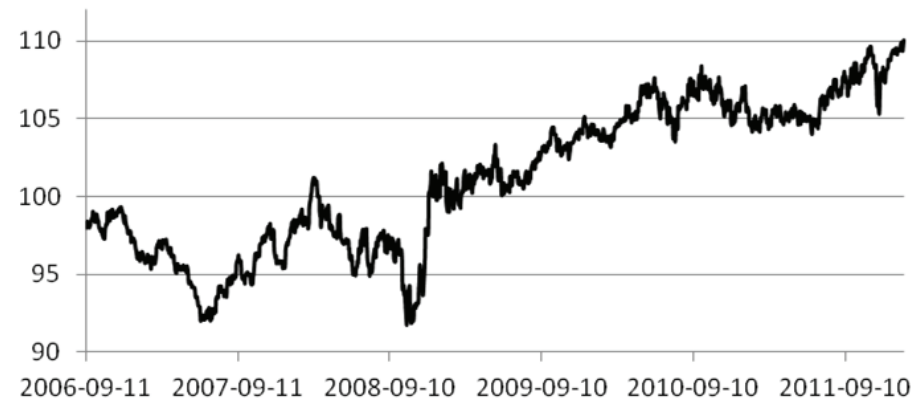

Fig. 3. German Treasury bill Bundesrepublik Deutschland-Anleihe: bis 15-04-2016 quotations Source: www.finanzen.net. 
When applying different efficiency measures we usually obtain different rankings ${ }^{39}$ of the mutual funds because the Treynor, Sharpe and Jensen ratios evaluate the fund efficiency from different points of view. Different results of the performance measurement are also expected due to the variety of the employed market indexes and periods of analysis that are characterized by different market situations. Therefore we construct simple synthetic measures to compare investigated mutual funds, using different efficiency ratios. The first aggregated measure is a sum of ranks obtained by each mutual fund regarding different features, such as:

- the single-period rate of return calculated for each of the analyzed period, and

- efficiency ratios, estimated for different market indexes and each of the analyzed periods:

$$
M S_{j}=\sum_{l=1}^{n} N_{l j}
$$

where $N_{l j}$ - number describing the position of the $j$-th mutual fund in the $l$-th ranking (obtained for the certain measure in the certain period).

Another aggregated measure is constructed on the basis of the created classes of the mutual funds performance:

$$
C S_{j}=\sum_{i=1}^{k} w_{i} p_{i j}
$$

where:

$p_{i j}-$ count of cases when the $j$-th mutual fund is classified to the $i$-th class of performance,

$w_{i}-$ is the weight describing the $i$-th class of performance.

\section{Results}

The presented nvestigation is carried out on the basis of daily quotations of all the analyzed financial instruments. As the first step of research, we evaluate the main time series characteristics such as: simple and logarithmic rates of return, expected returns and standard deviations, as well as skewness measures. We also verify basic hypothesis concerning profits and risk of the investments in the examined mutual funds and benchmarks ${ }^{40}$. Secondly, singleindex and CAPM models are estimated for all the funds and periods by means of different stock indexes. The third step consists of the Sharpe, Treynor and Jensen ratios evaluation for 
all the market indexes and distinguished periods of the analysis. Further research is conducted applying the aggregated measures described above.

Table 3 contains the rates of returns describing the "buy and hold" investment strategy (i.e. the instrument is bought on the first day and sold on the last day of each considered period) to characterize the situation of the European market. As one can notice in the whole analyzed period $\mathrm{T}$ the highest returns are obtained from DAX and T-Bills (about 12\%), both representing the German market, while other stock indexes and majority of mutual funds generate losses from investments. There are only 3 funds - Allianz, UIL and RAF that are characterized by positive returns however their efficiency is lower than the one observed for T-Bills. In the period denoted as T1 (i.e. before the LB bankruptcy) all funds but one ( RAF) as well as all benchmarks with the exception of DAX give negative returns. The situation changes in the period T2 (i.e. after LB bankruptcy) when positive returns are observed for DAX, FTSE and treasury bonds together with 6 mutual funds. It is worth mentioning that two of them generate $28 \%$ of returns, which is bigger than the benchmarks among which the T-Bills investment seems to be the

Table 3. One-period percentage rates of return

\begin{tabular}{|c|c|c|c|c|c|c|c|}
\hline \multicolumn{2}{|r|}{ Periods } & $\mathrm{T}$ & $\mathrm{T} 1$ & $\mathrm{~T} 2$ & B & B1 & B2 \\
\hline \multirow{18}{*}{$\begin{array}{l}\text { Mutual } \\
\text { Funds }\end{array}$} & Allianz & 10.69 & -10.00 & 28.04 & -8.63 & -50.16 & 91.64 \\
\hline & AXA & -31.63 & -15.06 & -16.85 & -38.15 & -61.45 & 65.59 \\
\hline & BlackRock & -3.11 & -2.47 & 3.04 & -17.18 & -51.95 & 77.12 \\
\hline & $\mathrm{CS}$ & -39.42 & -22.62 & -18.80 & -42.56 & -64.04 & 65.67 \\
\hline & Deka & -32.41 & -12.29 & -19.94 & -36.97 & -64.12 & 84.78 \\
\hline & DWS & -8.28 & -9.63 & 4.84 & -20.63 & -51.73 & 68.81 \\
\hline & Fidelity & -19.40 & -7.31 & -10.23 & -30.20 & -55.71 & 63.92 \\
\hline & FP & -27.27 & -14.86 & -12.13 & -35.78 & -62.20 & 78.34 \\
\hline & Henderson & -21.99 & -14.42 & -5.06 & -36.29 & -56.74 & 50.68 \\
\hline & FT & -31.25 & -16.40 & -14.61 & -38.14 & -60.62 & 65.31 \\
\hline & HSBC & -17.24 & -2.53 & -11.76 & -25.78 & -57.62 & 80.95 \\
\hline & Pioneer & -3.39 & -4.73 & 3.97 & -20.01 & -48.53 & 57.52 \\
\hline & RAF & 1.94 & 0.02 & 4.96 & -18.59 & -58.57 & 99.82 \\
\hline & SI & -20.88 & -11.36 & -7.16 & -31.98 & -56.94 & 60.26 \\
\hline & SEB & -29.36 & -13.09 & -15.29 & -31.89 & -60.83 & 80.91 \\
\hline & UI & -23.79 & -7.45 & -14.09 & -32.12 & -57.34 & 64.18 \\
\hline & UIL & 10.69 & -10.00 & 28.04 & -8.63 & -50.16 & 91.64 \\
\hline & Veritas & -19.89 & -11.31 & -4.63 & -26.62 & -57.12 & 78.23 \\
\hline \multirow{4}{*}{$\begin{array}{l}\text { Market } \\
\text { indexes }\end{array}$} & ES 50 & -34.89 & -12.40 & -22.68 & -36.86 & -59.35 & 55.94 \\
\hline & DAX & 12.31 & 7.53 & 7.38 & -15.38 & -53.93 & 82.41 \\
\hline & CAC 40 & -34.39 & -14.35 & -20.39 & -36.43 & -57.95 & 52.07 \\
\hline & FTSE 100 & -2.01 & -7.42 & 10.17 & -12.04 & -46.43 & 63.64 \\
\hline T-Bill & BDA & 12.00 & -1.64 & 13.08 & 15.36 & 9.21 & 5.28 \\
\hline
\end{tabular}

Source: own calculations. 
most profitable. Also in the periods denoted as B and B1 (bear market) the German treasury bond is the only instrument that generates positive rates of return. While in the period B2 (bull market) all instruments generate positive returns, however the T-bond is the least profitable and generates the smallest return, but one must notice that this instrument has had an upward tendency also during the bear market period while other instruments declined by more than $50 \%$ (only FTSE decreased by 46\%). Among the market indexes the highest return is visible for DAX, and only four mutual funds have better results in the period B2.

While analyzing the average rate of daily returns of the selected mutual funds and indexes, we can see that the majority of returns is negative but not significantly different from zero in all the analyzed periods but B1 and B2. In the former period the majority of the expected returns is significantly negative (with the exception of such funds as: BlackRock, Pioneer, SEB, UIL, Veritas, and benchmarks: FTSE and T-bills) while in the latter period the returns from all instruments are significantly positive except the treasury bonds. These conclusions are confirmed by the results of other tests ${ }^{41}$.

Table 4. Ranking and classification of funds due to the Sharpe ratio

\begin{tabular}{|c|c|c|c|c|c|c|c|c|c|c|c|c|}
\hline Mutual Funds & \multicolumn{2}{|c|}{$\mathrm{T}$} & \multicolumn{2}{|c|}{$\mathrm{T} 1$} & \multicolumn{2}{|c|}{$\mathrm{T} 2$} & \multicolumn{2}{|c|}{$\mathrm{B}$} & \multicolumn{2}{|c|}{ B1 } & \multicolumn{2}{|c|}{ B2 } \\
\hline Allianz & 2 & $* * *$ & 9 & $* *$ & 2 & $* * * *$ & 2 & $* * * *$ & 5 & $* * *$ & 13 & $* *$ \\
\hline AXA & 17 & $* *$ & 16 & & 17 & $*$ & 17 & & 18 & & 17 & $*$ \\
\hline BlackRock & 5 & $* * *$ & 3 & $* * *$ & 3 & $* * * *$ & 5 & $* * *$ & 6 & $* * *$ & 14 & $* *$ \\
\hline $\mathrm{CS}$ & 18 & & 18 & & 18 & $*$ & 18 & & 17 & & 9 & $* * *$ \\
\hline Deka & 16 & $* *$ & 13 & $* *$ & 15 & $* *$ & 14 & $* *$ & 16 & & 3 & $* * * *$ \\
\hline DWS & 6 & $* *$ & 8 & ** & 7 & $* *$ & 7 & $* *$ & 8 & $* *$ & 15 & $*$ \\
\hline Fidelity & 9 & $* *$ & 6 & $* * *$ & 12 & $* *$ & 10 & $* *$ & 10 & $*$ & 18 & \\
\hline FP & 14 & $* *$ & 15 & & 10 & $* *$ & 12 & $* *$ & 11 & $*$ & 4 & $* * * *$ \\
\hline Henderson & 13 & $* *$ & 14 & $* *$ & 16 & $*$ & 16 & & 9 & $* *$ & 11 & $* *$ \\
\hline FT & 15 & $* *$ & 17 & & 14 & $* *$ & 15 & & 15 & & 6 & $* * * *$ \\
\hline HSBC & 8 & $* *$ & 4 & $* * *$ & 8 & $* *$ & 9 & $* *$ & 12 & $*$ & 8 & $* * *$ \\
\hline Pioneer & 4 & $* * *$ & 5 & $* * *$ & 4 & $* * * *$ & 3 & $* * *$ & 2 & $* * * *$ & 2 & $* * * *$ \\
\hline RAF & 3 & $* * *$ & 2 & $* * *$ & 5 & $* * *$ & 4 & $* * *$ & 7 & $* * *$ & 5 & $* * * *$ \\
\hline SI & 10 & $* *$ & 12 & $* *$ & 11 & $* *$ & 13 & $* *$ & 13 & $*$ & 7 & $* * *$ \\
\hline SEB & 11 & $* *$ & 11 & $* *$ & 9 & $* *$ & 8 & $* *$ & 4 & $* * * *$ & 10 & $* * *$ \\
\hline UI & 12 & $* *$ & 7 & $* * *$ & 13 & $* *$ & 11 & $* *$ & 14 & $*$ & 12 & $* *$ \\
\hline UIL & 1 & $* * * *$ & 1 & $* * *$ & 1 & $* * * *$ & 1 & $* * * *$ & 1 & $* * * *$ & 16 & $*$ \\
\hline Veritas & 7 & $* *$ & 10 & $* *$ & 6 & $* *$ & 6 & $* *$ & 3 & $* * * *$ & 1 & $* * * *$ \\
\hline ES 50 & & $*$ & & $* *$ & & $*$ & & $*$ & & $*$ & & $* * *$ \\
\hline DAX & & $* * * *$ & & $* * * *$ & & $* * *$ & & $* * *$ & & $* * *$ & & $* * * *$ \\
\hline CAC 40 & & $* *$ & & $*$ & & $* *$ & & $* *$ & & $* *$ & & $*$ \\
\hline FTSE 100 & & $* * *$ & & $* * *$ & & $* * * *$ & & $* * * *$ & & $* * * *$ & & $* *$ \\
\hline
\end{tabular}

Source: own calculations. 
After the evaluation of classical performance measures, all the examined funds are ranked in a descending order, so the first position is held by the most effective mutual fund. There are 6 such rankings for the Sharpe ratio (see Table 4) and returns employing the strategy "buy and hold" (Table 3), and there are 24 classifications for the Treynor and Jensen ratios separately because these measures are evaluated for four markets ${ }^{42}$. Therefore in the aggregated measures (1) and (2) 60 classifications of each mutual fund were employed.

In our investigation the ranking is made in a descending order, hence the smaller value of $M S_{j}(1)$ denotes better performance of the mutual fund. In the synthetic measure defined by (2) the number of the distinguished performance classes $k=5$, and $p_{i j}$ informs how many times the $j$-th mutual fund is classified to the $i$-th class of performance, while $w_{i}$ denotes the number of stars in the class description i.e. $w_{i}=0,1, \ldots, 4$ (i.e. for $* * * *, k=4$ ). We assume that better performance is characterized by a bigger value of $w_{i}$, therefore for the bigger value of $C S_{j}$ the mutual fund performances are better.

To construct (2) we classify each fund to one of five pre-defined performance classes, taking into account the applied measures of the mutual funds performance. These classes are defined separately for:

1. the Treynor and Sharpe ratios,

2. Jensen's alpha,

3. the single-period rate of return.

In the first classification we start from the efficiency evaluation of the markets that are described by the indexes: ES 50, DAX, CAC 40 and FTSE 100 and rank them from the most $(* * * *)$ to the least $(*)$ effective, which is visible in the four last rows in Table 4 for the Sharpe index. As one can notice the German and British markets always perform better than the French and the eurozone markets although they share the leader position in different periods. Next,we classify the mutual funds into 5 classes of funds that, in a certain period, perform:

1. better than the best market index (which is denoted in Table 4 by ****),

2. better than the second (but worse than the first) market index $(* * *)$,

3. better than the third (but worse than the second) market index $(* *)$,

4. better than the last (but worse than the third) market index $\left(^{*}\right)$,

5. worse than the last (fourth) market index.

For Jensen's alpha we classify funds due to the value of the rate:

$$
J=\frac{\text { Jensen } \text { alpha }}{\text { beta }}
$$


and classes are created by the funds that, for a certain period and market index, obtained $J$ value which is:

1. the biggest (which is denoted in Table 4 by $* * * *$ );

2. the second and the third the biggest $(* * *)$;

3. smaller than three biggest $J_{\mathrm{S}}$ but bigger than three smallest $J_{\mathrm{S}}(* *)$;

4. the second and the third smallest (*),

5. the smallest

since $J$ for all the analyzed funds is negative.

Taking into consideration the returns from the investment strategy "buy and hold", we evaluate quartiles for the rates of returns generated by all the mutual funds in each period of this analysis, we also look at the performance of benchmarks. Five classes are constructed as following:

1. the funds that obtained either the returns better than the best achieved benchmark for the positive value of the third quartile (i.e. the periods T2 and B2) or positive returns otherwise ( which is denoted in Table 4 by $* * * *$ );

2. the funds that obtained returns either bigger than the third quartile but smaller than the best achieved benchmark for the positive value of the third quartile (i.e. the periods T2 and B2) or negative returns otherwise $(* * *)$;

3. the funds that obtained returns bigger than the median and smaller than the third quartile $(* *)$;

4. the funds that obtained returns smaller than the median and bigger than the first quartile $(*)$;

5. the funds that obtained returns smaller than the first quartile.

In Table 5 the classification of the mutual funds into five pre-defined performance classes is presented together with the ranking of funds on the basis of the aggregated measures $M S_{j}$ (1) and $C S_{j}$ (2). It can be noticed that, although the big differences in the mutual funds ranking obtained by single (individual) measure are observed, the application of the aggregated measures generate similar rankings.

Another question that arises concerns persistence in mutual funds performance therefore we construct the ranking of the analyzed funds based on (1) for both pairs of the analysed sub-periods. In other words, $S M_{j}$ is evaluated separately for: T1, T2, B1 and B2, hence in $M_{j}$ construction 10 rankings (separately for each period) are taken into account. 
Table 5. Ranking of mutual funds due to aggregated measures

\begin{tabular}{|c|c|c|c|c|c|c|c|c|c|}
\hline \multirow[b]{2}{*}{ Mutual Funds } & \multicolumn{5}{|c|}{$\begin{array}{l}\text { Number of cases } \\
\text { when the fund is classified to the class }\end{array}$} & \multicolumn{4}{|c|}{$\begin{array}{c}\text { Ranking } \\
\text { due to aggregated measures }\end{array}$} \\
\hline & & $*$ & $* *$ & $* * *$ & $* * * *$ & $C S_{j}(2)$ & $\mathrm{N}^{\circ}$ & $M S_{j}(1)$ & $\mathrm{N}^{\circ}$ \\
\hline Allianz & 9 & 6 & 16 & 22 & 7 & 132 & 2 & 328 & 5 \\
\hline AXA & 29 & 9 & 20 & 1 & 1 & 56 & 17 & 916 & 17 \\
\hline BlackRock & 9 & 5 & 17 & 28 & 1 & 127 & 3 & 305 & 3 \\
\hline $\mathrm{CS}$ & 44 & 7 & 6 & 2 & 1 & 29 & 18 & 951 & 18 \\
\hline Deka & 25 & 10 & 21 & 1 & 3 & 67 & 13 & 782 & 14 \\
\hline DWS & 12 & 5 & 39 & 3 & 1 & 96 & 6 & 443 & 7 \\
\hline Fidelity & 22 & 5 & 29 & 3 & 1 & 76 & 11 & 594 & 10 \\
\hline FP & 26 & 15 & 12 & 4 & 3 & 63 & 15 & 786 & 15 \\
\hline Henderson & 26 & 13 & 19 & 1 & 1 & 58 & 16 & 830 & 16 \\
\hline FT & 27 & 6 & 24 & 1 & 2 & 65 & 14 & 771 & 13 \\
\hline HSBC & 13 & 7 & 33 & 6 & 1 & 95 & 7 & 373 & 6 \\
\hline Pioneer & 12 & 4 & 26 & 14 & 4 & 114 & 5 & 272 & 2 \\
\hline RAF & 10 & 5 & 22 & 18 & 5 & 123 & 4 & 320 & 4 \\
\hline SI & 19 & 6 & 32 & 2 & 1 & 80 & 9 & 583 & 9 \\
\hline SEB & 22 & 7 & 27 & 2 & 2 & 75 & 12 & 700 & 12 \\
\hline UI & 18 & 8 & 31 & 2 & 1 & 80 & 10 & 654 & 11 \\
\hline UIL & 2 & 11 & 9 & 16 & 22 & 165 & 1 & 208 & 1 \\
\hline Veritas & 17 & 13 & 22 & 5 & 3 & 84 & 8 & 444 & 8 \\
\hline
\end{tabular}

Source: own calculations.

While classifying the funds due to 10 performance measures we can see that in the periods $\mathrm{T} 1$ and T2 four funds keep their position in ranking (i.e. BlackRock, CS, SI and UIL), while in the periods B1 and B2 there is only one such fund - FT). We also find out that some funds are ranked identically by all measures for the single-period analysis. These funds are: CS, Fidelity, Pioneer, RAF, UI and UIL in the T1 period; Allianz, BlackRock, CS, SEB and UIL in T2, and only two funds - UIL and CS (on the first and the last position) in the B1 period.

Also, the distance that appears between the ranking positions achieved in both $\mathrm{T}$ periods is much smaller in comparison to the periods B1 and B2. It results from the market situation since both B periods are constructed taking into account the opposite market trends i.e. the bear and bull markets although both periods cover the time span of the worldwide financial crisis. Comparing the funds ranking in B1 and B2 we notice that the leader in the rankings provided for T1, T2 and B1 periods, i.e. UIL, lost its position in the period B2 being classified as the 16th fund. While the "weak" FP moved from the last position in the B1 period to the second one in the B2 period. 
Table 6. Comparison of mutual fund ranking in two subperiods

\begin{tabular}{|c|c|c|c|c|c|}
\cline { 5 - 6 } \multicolumn{1}{c|}{} & \multirow{2}{*}{ T1 } & \multirow{2}{*}{ T2 } & & B1 & B2 \\
\hline Allianz & 9 & 2 & Allianz & 4 & 14 \\
\hline AXA & 14 & 17 & AXA & 14.5 & 17 \\
\hline BlackRock & 3 & 3 & BlackRock & 2 & 15 \\
\hline CS & 18 & 18 & CS & 17.5 & 6 \\
\hline Deka & 13 & 15 & Deka & 16 & 3 \\
\hline DWS & 8 & 6 & DWS & 5 & 13 \\
\hline Fidelity & 6 & 11 & Fidelity & 8 & 18 \\
\hline FP & 15 & 14 & FP & 17.5 & 2 \\
\hline Henderson & 17 & 16 & Henderson & 13 & 9 \\
\hline FT & 16 & 13 & FT & 10 & 10 \\
\hline HSBC & 4 & 7 & HSBC & 7 & 5 \\
\hline Pioneer & 5 & 4 & Pioneer & 3 & 4 \\
\hline RAF & 2 & 5 & RAF & 12 & 7 \\
\hline SI & 10 & 10 & SI & 9 & 8 \\
\hline SEB & 12 & 9 & SEB & 14.5 & 11 \\
\hline UI & 7 & 12 & UI & 11 & 12 \\
\hline UIL & 1 & 1 & UIL & 1 & 16 \\
\hline Veritas & 11 & 8 & Veritas & 6 & 1 \\
\hline
\end{tabular}

Source: own calculations.

Note, fraction numbers in the column B1 mean that there are two pairs of mutual funds for which $M S_{j}$ is equal so both funds obtained the same position - the average.

\section{Conclusions}

In the paper we look at the efficiency of mutual funds operating in Europe taking into consideration the best performing 18 pan-European funds. The performance analysis is conducted in different periods, by means of classical efficiency ratios that are employed to construct the synthetic measure. Our results show that the German stock market, represented by DAX, performs the best in comparison to other examined European markets. Therefore the decision of selecting a benchmark can have a significant effect on the evaluation of a portfolio performance.

Our research also proves that although the big differences in the mutual funds ranking (obtained by a single ratio) are observed, the application of the aggregated measure generates similar rankings. We also find out that there is no persistence in the performance of the analyzed mutual funds. Great differences in the mutual fund rankings are observed especially when the comparison is provided for different situations on the market. Therefore, to evaluate the mutual 
funds efficiency it is necessary to conduct a "multi-criteria" performance analysis considering different benchmarks, market situations and measures.

We realize that our results may be biased by a small number of funds and the criteria of the European mutual funds' selection, which results inall the funds having to to have a portfolio that is diversified in terms of "international investment". In fact, in case of all the portfolios the share of any individual country was not bigger than $41 \%$ i.e. among the analyzed funds there were no such funds that invested solely on the domestic market, which could influence their performance.

\section{Notes}

1 Jensen (1968).

${ }^{2}$ Hendricks et al. (1993).

${ }^{3}$ e.g., see Ippolito (1992); Sirri, Tufano (1993); Patel et al. (1994), pp. 34-48; Gruber (1996); Goetzmann, Peles (1997); Edelen (1999); Bergstresser, Poterba (2002); Deaves (2004); Busse, Irvine (2006).

${ }^{4}$ Wermers (2000).

${ }^{5}$ The Fidelity Magellan Fund is a US-domiciled mutual fund from the Fidelity Investments family of funds. It is perhaps the world's best known actively managed mutual fund.

${ }^{6}$ As the industry's first index fund for individual investors, the 500 Index Fund is a low cost way to gain diversified exposure to the U.S. equity market. The fund invests in 500 of the largest U.S. companies, which span many different industries and account for about three-fourths of the U.S. stock market's value. The key risk for the fund is the volatility that comes with its full exposure to the stock market. Because the 500 Index Fund is broadly diversified within the large-capitalization market, it may be considered a core equity holding in a portfolio; https://personal. vanguard.com/us/FundsSnapshot?FundId=0040\&FundIntExt=INT.

${ }^{7}$ Gruber (1996).

${ }^{8}$ Carhart (1997).

${ }^{9}$ Ding, Wermers (2009).

${ }^{10}$ Bello, Frank (2010).

11 Gil-Bazo, Ruiz-Verdú (2009).

12 Gruber (1996).

13 Gil-Bazo, Ruiz-Verdú (2009).

14 Treynor (1965); Sharpe (1966); Jensen (1968); Jensen (1969).

15 Fletcher (1995); Jensen (1968).

${ }^{16}$ Roll (1978); Reilly, Akhtar (1995); Grinblatt, Titman (1994).

17 Lehmann, Modest (1987).

18 Matallin-Saez (2007).

19 Dutta et al. (2010).

20 Prince, Bacon (2010).

${ }^{21}$ Otten, Bams (2002); Otten, Schweitzer (2002).

22 The SBF 250 (Société des Bourses Françaises 250 Index) is a French stock market index representing all sectors of the French economy; Bangash (2012).

${ }^{23}$ The CISDM equity long/short index is one of 13 Commodity Trading Advisor (CTA) indexes that represent average performances of three CTA strategies in the Morningstar CISDM Hedge Fund/CTA Database. In all index 
calculations, duplicate CTAs (versions of CTAs that differ only in location or currency) are eliminated. Also, any average index performance does not include outliers, www.isenberg.umass.edu/CISDM/Hedge_FundCTA_Indices; Manser, Schmid (2009).

${ }^{24}$ Karpio, Żebrowska-Suchodolska (2011).

${ }^{25}$ See Hendricks et al. (1993); Carhart (1997); Derwall, Huij (2008); Dutta et al. (2010); Pätäri (2009).

${ }^{26}$ (Pätäri, 2009).

27 Broad literature review can be found in Pätäri, 2009.

${ }^{28}$ Bangash (2012); Otten, Bams (2002); Otten, Schweitzer (2002) or Price, Bacon (2002).

${ }^{29}$ Collinet, Firer (2003)ł Droms, Walker (2001).

${ }^{30}$ Harlow, Brown (2006).

${ }^{31}$ For instance Kahn, Rudd (1995) investigate a 3-year period while Kosowski et al. (2006) - a 28-year one.

${ }^{32}$ See 2012 Investment Company Fact Book.

${ }^{33} \mathrm{http}: / /$ funds.ft.com/uk/Screener.

${ }^{34}$ The major data supplier is Morningstar, Inc. 2012.

${ }^{35}$ Europe Large-Cap Blend Equity funds are fairly representative of the overall European equity market (including the UK) in size, growth rates and price. Equities in the top $70 \%$ of the European equity market (including the UK) are defined as large-cap. The blend style is assigned to funds where neither growth nor value characteristics predominate. These funds tend to invest across the spectrum of European industries. At least $75 \%$ of total assets are invested in equities and at least $75 \%$ of equity assets are invested in European equities. Morningstar Category Definition - European and Asia Morningstar Methodology Paper May 2011.

${ }^{36}$ Trailing total return is the full return on an investment over a given period, including the income generated from dividend, interest or rental payments, and any gains or losses from a change in the asset's market value. The returns were calculated at the beginning of year 2012.

${ }^{37}$ Not all mutual funds (e.g. Henderson and Veri-Europa) inform about the investment structure therefore the analysis is provided due to available data.

${ }^{38}$ The EURO STOXX 50 Index, Europe's leading blue-chip index for the eurozone, provides a blue-chip representation of supersector leaders in the eurozone. The index covers 50 stocks from 12 eurozone countries: Austria, Belgium, Finland, France, Germany, Greece, Ireland, Italy, Luxembourg, the Netherlands, Portugal and Spain.

${ }^{39}$ Rankings of investment funds are quite often prepared by different institutions and authors. To construct such rankings the variety of criteria is taken into account. Usually the rankings are built on the basis of one characteristic (often the rate of return), however there are some examples of taxonomic measures applied to construct the ranking, for instance Kosarga (2002); Kompa, Witkowska (2010) and Prince, Bacon (2010).

${ }^{40}$ All hypothesis are verified at the significance level 0.05 .

${ }^{41}$ Some results are presented in Foo, Witkowska (2012) and Lachowski (2012).

${ }^{42}$ Classifications due to Treynor and Jensen ratios are presented in Witkowska (2012).

\section{References}

Bangash, R. (2012). Evaluation of European Mutual Funds Performance. World Journal of Social Sciences, Vol. 2, No. 1, 154-173.

Bello, Z. \& Frank, L. (2010). A Re-examination of the Impact of Expenses on the Performance of Actively Managed Equity Mutual Funds. European Journal of Finance \& Banking Research, Vol. 3, Issue 3, 39-49. 
Bergstresser, D. \& Poterba, J.M. (2002). Do After-Tax Returns Affect Mutual Fund Inflows? Journal of Financial Economics 63, 381-414.

Busse, J.A. \& Irvine, P.J. (2006). Bayesian Alphas and Mutual Fund Persistence. Journal of Finance 61, 2251-2288.

Carhart, M.M. (1997). On Persistence in Mutual Fund Performance. Journal of Finance, Vol. 52, No. 1, 57-82.

Collinet, L. \& Firer, C. (2003). Characterizing Persistence of Performance amongst South African General Equity Unit Trusts. Omega, Vol. 31, No. 6, 523-538.

Deaves, R. (2004). Data-conditioning Biases, Performance, Persistence and Flows: The Case of Canadian Equity Funds. Journal of Banking and Finance, Vol. 8, 673-694.

Derwall, J. \& Huij, J. (2008). "Hot Hands" in Bond Funds. Journal of Banking and Finance, Vol. 32, 559-572.

Ding, B. \& Wermers, R. (2009). Mutual Fund Performance and Governance Structure: The Role of Portfolio Managers and Boards of Directors, www.business.uconn.edu/fina nce/ seminars/papers/Wermers.pdf.

Droms, W.G. \& Walker, D.A. (2001). Performance Persistence of International Mutual Funds. Global Finance Journal, Vol. 12, No. 2, 237-248.

Dutta, A.S., Su, R. \& Xu, M. (2010). Persistence in New Zealand Growth Mutual Funds Returns: An Examination of New Zealand Mutual Funds from 1997-2003. Indian Journal of Economics \& Business, Vol. 9, No. 2, 303-314.

Edelen, R.M. (1999). Investor Flows and the Assessed Performance of Open-end Mutual Funds. Journal of Financial Economics, Vol. 53, 439-466.

Fletcher, J. (1995). The evaluation of Managed Fund Performance. British Accounting Review, Vol. 27, 127-138.

Foo, J. \& Witkowska, D. (2012). Mutual Funds Efficiency Comparison between U.S. and Europe, paper presented at International Atlantic Economic Society Conference, Istanbul.

Gil-Bazo, J, \& Ruiz-Verdu, P. (2009). The Relation between Price and Performance in the Mutual Fund Industry. Journal of Finance, Vol. 64, No. 5, 2153-2183.

Goetzmann, W.N. \& Peles N. (1997). Cognitive Dissonance and Mutual Fund Performance. Journal of Financial Research, Vol. 20, 145-158.

Grinblatt, M. \& Titman, S. (1994). A Study of Monthly Mutual Fund Returns and Performance Evaluation Techniques. Journal of Financial and Quantitative Analysis, Vol. 29, No. 3, 419-444.

Gruber, M.J. (1996). Another Puzzle: The Growth in Actively Managed Mutual Funds. Journal of Finance, Vol. 51, No. 3, 783-810. 
Harlow, W. \& Van Brown, K.C. (2006). The Right Answer to the Wrong Question: Identifying Superior Active Portfolio Management. Journal of Investment Management, Vol. 4, $1-26$.

Hendricks, D., Patel, J. \& Zeckhauser, R.J. (1993). Hot Hands in Mutual Funds: Short-Run Persistence of Relative Performance, 1974-1988. Journal of Finance, Vol. 48, 93-130.

Ippolito, R.A. (1992). Consumer Reaction to Measures of Poor Quality: Evidence from the Mutual Fund Industry. Journal of Law and Economics, Vol. 35, 45-70.

Jensen, M.C. (1968). The performance of Mutual Funds in the period 1945-1964. Journal of Finance, Vol. 23, No. 2, 389-416.

Jensen, M.C. (1969). Risk, the pricing of capital assets, and the evaluation of investment portfolios. Journal of Business, Vol. 42, Issue 2, 167-247.

Kahn, R.N. \& Rudd, A. (1995). Does Historical Performance Predict Future Performance? Financial Analysis Journal, Vol. 51, No. 6, 43-52.

Karpio, A. \& Żebrowska-Suchodolska, D. (2011). Stability of Strategies of Polish Open-end Investment Funds Investing in Global Markets during the Financial Crisis. Acta Scientiarum Polonorum, Oeconomia, Vol. 10, No. 3, Warszawa: SGGW, 51-59.

Kompa, K. \& Witkowska, D. (2010). Comparison of the Open-End Investment Funds Efficiency at Bull and Bear Markets. Acta Scientiarum Polonorum, Oecomnomia, Vol. 9, No. 3, Warszawa: SGGW, 169-180 (in Polish).

Kosarza, R. (2002). Ranking funduszy inwestycyjnych: fundusze zrównoważone na pierwszy ogień, www.bankier.pl/wiadomosc/Ranking-funduszy-inwestycyjnych-fundusze-zrowno wazone-na-pierwszy-ogien-343224.html.

Kosowski, R., Timmermann, A., Wermers, R. \& White H. (2006). Can Mutual Funds "Stars" Really Pick Stocks? New Evidence from Bootstrap Analysis. Journal of Finance, Vol. 61, 54-56.

Lachowski, S. (2012). Ocena efektywności europejskich otwartych funduszy inwestycyjnych. Warszawa: SGGW, Master Thesis prepared under D. Witkowska supervision.

Lehmann, B.N. \& Modest, D.M. (1987). Mutual Fund Performance Evaluation: A Comparison of Benchmarks and Benchmark Comparisons. Journal of Finance, Vol. 42, No. 2, $233-265$.

Matallin-Saez, J.C. (2007). Portfolio performance: factors or benchmarks? Applied Financial Economics, Vol. 17, 1167-1178.

Manser, S. \& Schmid, M.M. (2009). The Performance Persistence of Equity Long/Short Hedge Funds. Journal of Derivatives and Hedge Funds, Vol. 15, No. 1, 51-69.

Morningstar Category Definition - European and Asia Morningstar Methodology Paper, May 2011, http://corporate.morningstar.com/it/documents/MethodologyDocuments/Methodo logyPapers/EuropeAsiaCategoryDefinitionsMeth.pdf. 
Otten, R. \& Bams, D. (2002). European Mutual Fund Performance. European Financial Management, Vol. 8, No. 1, 75-101.

Otten, R. \& Schwitzer, M. (2002). A Comparison between the European and the U.S. Mutual Fund Industry. Managerial Finance, Vol. 28 (1), 14-35.

Patel, J., Zeckhauser, R.J. \& Hendricks, D. (1994). Investment Flows and Performance: Evidence from Mutual Funds, Cross-Border Investments and New Issues. In: Japan, Europe and International Financial Markets: An Analytical and Empirical Perspective, R. Sato, R. Levich, R.V. Ramachanday (Eds.), Cambridge: England.

Pätäri, E.J. (2009). Do Hot Hands Warm the Mutual Fund Investor? The Myth of Performance Persistence Phenomenon. International Research Journal of Finance and Economics, No. 34, www.eurojournals.com/finance.htm.

Prince, T. \& Bacon, F. (2010). Analyzing Mutual Fund Performance against Established Performance Benchmarks: A Test of Market Efficiency. Research in Business and Economic Journal, Vol. 1, www.aabri.com/manuscripts/08112.pdf.

Reilly, F. \& Akhtar, R. (1995). The Benchmark Error Problem with Global Capital Markets. Journal of Portfolio Management, Vol. 22, No. 1, 33-50.

Roll, R.R. (1978). Ambiguity When Performance is Measures by the Securities Market Line. Journal of Finance, Vol. 33, 1051-1069.

Sharpe, W.F. (1966). Mutual Fund Performance. Journal of Business, Vol. 39, No. 1, 119138.

Sirri, E.R. \& Tufano, P. (1993). Buying and Selling Mutual Funds: Flows, Performance, Fees, and Services, Working Paper, Harvard Business School.

Treynor, J.L. (1965). How to Rate Management of Investment Funds. Harvard Business Review, 43, No. 1, 63-75.

Wermers, R. (2000). Mutual Fund Performance: An Empirical Decomposition into Stock-Picking Talent, Style, Transaction Costs, and Expenses. Journal of Finance, Vol. 55, 16551695.

Witkowska, D. (2012). Budowa mierników syntetycznych do oceny efektywności europejskich funduszy inwestycyjnych, Metody Ilościowe w Badaniach Ekonomicznych, Vol. XIII, No. 3, Warszawa: SGGW Press, pp. 262-275. 